\title{
Marine Algae as Natural Indicator of Environmental Cleanliness
}

\author{
Anna Parus (iD • Bożena Karbowska
}

Received: 24 September 2019 / Accepted: 20 January 2020 /Published online: 19 February 2020

(C) The Author(s) 2020

\begin{abstract}
Algae are widely distributed in the aquatic environment. In the analyzed algae from the Black Sea, metals like cadmium, iron, zinc, copper, lead, and thallium were present. From all of the analyzed elements in the algae, iron was present at the highest concentrations. The presented study confirmed that thallium is accumulated in relatively large quantities (1.60$2.12 \mu \mathrm{g} \mathrm{g}^{-1}$ ) by all the studied algae. Cadmium and copper were accumulated at the same level (1.98 $\mathrm{\mu g} \mathrm{g}^{-1}$ ), which was lower in comparison to the average concentrations determined in the analyzed plant material. The average amounts of zinc were at $0.21 \mu \mathrm{g} \mathrm{g}^{-1}$ for Ulva. High possibility of accumulation of metals by Ulva and Cystoseira allows to use them as a natural indicator of environmental cleanliness.
\end{abstract}

Keywords Algae - Metal accumulation cadmium · Differential-pulse anodic stripping voltammetry (DPASV) · Toxicity · Thallium

\footnotetext{
A. Parus $(\bowtie)$

Poznan University of Technology, Institute of Chemical Technology and Engineering, Berdychowo 4, 60-965 Poznan, Poland

e-mail: anna.parus@put.poznan.pl

B. Karbowska

Poznan University of Technology, Institute of Chemistry and Technical Electrochemistry, Berdychowo 4, 60-965 Poznan, Poland
}

\section{Introduction}

Metals are considered as one of the most hazardous pollutants in the environment due to their persistence in the environment, bioaccumulation, and high toxicity. The source of metals in the coastal area of the Black Sea is from anthropogenic activity, such as wastewater outflows, industrial sludge, river discharges, airborne inputs, rainfall, and dust precipitation (Idris 2008). The concentration of metals in water is low and varies de pending on environmental factors. Metal concentrations in the sediment depend on the oxidation-reduction potential, organic content, $\mathrm{pH}$, and the grain size composition (Akcali and Kucuksezgin 2011; Topcuoglu et al. 2003). The pollution levels of the aquatic environment by metals can be estimated by analyzing water, sediments, and marine organisms (Karbowska 2016). Marine organisms are one of the most reliable indicators for identifying sources of biologically available metal contaminations (Bazzi 2014).

The biomonitoring process has been widely used to establish the contamination with metals in the last two decades (Zelika et al. 2003; Nicholson and Lam 2005; Stanly et al. 2008). Different types of organisms may be used for biomonitoring, for example, marine algae and filter-feeding molluscs (Zortia et al. 2006a, b; Hamed and Emara 2006). Many studies showed that biovalves did not regulate the level of some metals within their body and the level of accumulated metals depends on the contamination of surrounding areas. Thus, biovalves can be considered as good biomonitoring agents for metal monitoring in aquatic ecosystems (Zelika et al. 
2003; Zortia et al. 2006b; Hamed and Emara 2006; Elfwing and Tedengreen 2002; Yap et al. 2002; Vlahogianni et al. 2007; Maanan 2008). On the other hand, seagrass and algae can also be used as bioindicators and give information on concentrations of metals or bioavailability of metals in the surrounding environment (Akcali and Kucuksezgin 2011; Ferrat et al. 2003a, b; Campanella et al. 2004). In general, algae are widely distributed in the aquatic environmental and are sedentary, easy to collect, identify, their bioaccumulation of trace metals occurs efficiently and they can meet the requirements for bioindicators (Ferrat et al. 2003a, b; Campanella et al. 2004; Conti and Cecchetti 2003). The cell wall of algae is consist of a variety of polysaccharides and proteins, and some of them contain anionic carboxyl, sulfate, or phosphate groups which are excellent binding sites for metal retention. Algae are able to accumulate trace metals, reaching concentration values which are thousands of times higher than their corresponding concentration in seawater (Conti and Cecchetti 2003). Algae bind only free metal ions, the concentrations of which depend on the nature of suspended particulate matter, which occurs in the form of organic and inorganic complexes. In summer, the number of visitors to the Black Sea area increases, hence the human activity in this site intensifies which reflects the change in the environmental conditions (Khaled and Hussein 2014).

The available quantitative data regarding the concentration of metals in seaweeds and general pollution of this area is limited. Therefore, the investigation of lead, cadmium, zinc, iron, copper, and thallium content in algae Cystoseiri sp., Ulva sp., and sand from west coast of the Black Sea is of importance.

Plants are the main link in the transfer of metals from contaminated soil to organisms, and in the next step, metals tend to accumulate in the food chain. As feed ingredients metals such as zinc, copper, and iron are essential for biological and physiological functions in the human body. However, the increase of consumption beyond a certain limit may result in toxic effects (Korfali et al. 2013a, b). Thallium, cadmium, and lead are common toxic metals in the environment (Nordberg et al. 2011; Goyer and Clarkson 2001). Little is known about the toxic modes of action of $\mathrm{Tl}$ in living cells and more or less about plant biota. Although in literature, several mechanisms have been proposed based on experimental evidence on the mammalian. Toxicity appears in good part due to the chemical similarity between $\mathrm{Tl}$ and $\mathrm{K}$ and the inability of cells to differentiate between these two metals. Tl competes for uptake through the $\mathrm{Na} / \mathrm{K}$ ATPase port. Given the high capacity of this membrane transporter to accumulate elevated concentrations of $\mathrm{K}$, there is a strong potential for cells to accumulate $\mathrm{Tl}$, which can then competitively interfere with any Kdependent physiological processes. For instance, Tl can replace $\mathrm{K}$ as an activating cofactor of enzymes such as pyruvate kinase and aldehyde dehydrogenase. Thallium can also replace the K used for ribosome stabilization and muscle contraction. Thallium is preferentially accumulated by some organelles such as mitochondria. The little evidence available suggests that toxic modes of action could involve membrane damage through phospholipid oxidation of mitochondria and of the endoplasmic reticulum, which would in turn affect membrane-bound physiological processes, such as ATPase activity. Furthermore, Tl may also affect membrane function through modifications of bilayer fluidity and phospholipid hydration, leading to increased permeabilization. The high affinity of $\mathrm{Tl}$ for sulfhydryl groups in enzymes and other molecules has also been invoked as a cause of toxicity. In mammals, Tl oxidizes the antioxidant GSH and inhibits glutathione peroxidase; inhibition of the antioxidant system may be one important mode of toxic action for Tl. This mechanism has also been observed in fish (Rodríguez-Mercado and Altamirano-Lozano 2013).

The aim of this work was to characterize the most common algae species distributed along the Bulgaria coast in terms of accumulation of thallium, cadmium, zinc, copper, lead, and iron.

\section{Materials and Methods}

\subsection{Sample Preparation and Analysis}

The study area was located in the western zone of the Black Sea coast, approx. $17 \mathrm{~km}$ north of Varna. Algae were collected manually in the tidal zone. Three types of algae derived Cryptogamia class, Cystoseira genus, and Ulva algae were collected in the summer of 2017. Samples were collected between 10 am and $12 \mathrm{pm}$, which generally corresponded to rising daily temperature and solar radiation conditions. The selected samples were collected at a similar stage of development. After washing (in the place of seawater), the samples were rinsed in deionized water in order to avoid losses of metal during 
treatment. The algae samples were then dried at $60^{\circ} \mathrm{C}$ to constant mass and ground in an agate mortar.

Samples of the top layer of sand (0-20 cm layer) were taken from several selected measuring positions located along the Black Sea coast. Take water-dried sand and pass through a $1 \mathrm{~mm}$ sieve to remove stones and root residues.

All solutions were prepared in high purity water obtained by reverse osmosis in a Watek-Demiwa 5 Rosa system (Czech Republic), followed by a triple distillation from a quartz apparatus. Only freshly distilled water was used.

\subsection{Instrumentation}

A $\mu$ Autolab electrochemical analyzer from EcoChemie (Utrecht, Netherlands) was used for electrochemical measurements. A standard three-electrode configuration, consisting of a mercury film electrode based on glassy carbon (which was used as a working electrode), $\mathrm{Ag} / \mathrm{AgCl}(3 \mathrm{M} \mathrm{KCl})$ reference, and $\mathrm{Pt}$ wire counter electrodes, was incorporated into a glass cell $(V=$ $20 \mathrm{~cm}^{3}$ ).

The metal ions concentrations were measured using atomic absorption spectrometry (AAS) with a Z-8200 spectrometer equipped with premix fishtail type burner - air/acetylene and $\mathrm{NO}_{2}$ /acetylene, graphite furnace flame, and furnace on the same beam made by Hitachi, Japan.

\subsection{Solutions and Preparations}

Standard solutions of $\mathrm{Tl}$ and other analyzed metals were prepared by dilution of a $1000-\mu \mathrm{g} \mathrm{ml}^{-1}$ stock standard solution obtained from Sigma Aldrich. Ammonia solution (25\%), nitric acid (65\%), hydrofluoric acid (73\%), hydrogen peroxide (30\%), EDTA, and ascorbic acid (supplied by Sigma Aldrich) were used to conduct the determination.

2.4 Determination of Thallium in the Algae Samples by the Voltammetric Method

Determination of thallium in the algae samples was conducted using a previously described procedure (Karbowska 2016; Karbowska and Zembrzuski 2016). Samples of the studied algae $(0.25 \mathrm{~g})$ were placed in a teflon beaker and digested by adding $65 \%$ nitric acid and $2.5 \mathrm{~cm}^{3}$ of $30 \%$ hydrogen peroxide. Upon evaporation of the solution, the residues were mixed with an additional dose of nitric acid $\left(1 \mathrm{~cm}^{3}\right)$, covered with glass, and heated for $3 \mathrm{~h}$. After filtration, the residues were mixed with ascorbic acid $\left(2.5 \mathrm{~cm}^{3}\right.$ of $1 \mathrm{M}$ solution) and EDTA $\left(6.25 \mathrm{~cm}^{3}\right.$ of $0.2 \mathrm{M}$ solution). The $\mathrm{pH}$ of the solution was then adjusted to a value of 4.5 (using an ammonium solution), then it was transferred to a flask $\left(25 \mathrm{~cm}^{3}\right)$ and supplemented with water. This final solution was used for the determination of thallium in the samples using differential pulse anodic stripping voltammetry (DPASV). The pre-concentration of Tl was carried out at a potential of $-900 \mathrm{mV}$ vs. SCE over 900-3600 s depending on the $\mathrm{Tl}$ concentration. Voltammograms were recorded after medium exchange for pure $0.05 \mathrm{M}$ EDTA. The results were evaluated on based on several additions of an internal standard (typically 3 additions). The detection limit of the method (calculated on a $3 \mathrm{SD}$ basis) was $50 \mathrm{pg} \mathrm{L}^{-1}(0.25 \mathrm{pM})$.

\subsection{Determination of Metals in the Algae Samples by AAS}

The algae samples $(0.25 \mathrm{~g})$ were digested in teflon vessels for $2 \mathrm{~h}$ with a mixture of $65 \% \mathrm{HNO}_{3}$ and $73 \%$ HF acids, respectively, according to the method described by Lukaszewski et al. (2012). The metals (Fe, $\mathrm{Cd}, \mathrm{Pb}, \mathrm{Zn}$, and $\mathrm{Cu}$ ) were analyzed using flame-atomic absorption spectrophotometer (AAS).

\section{Results and Discussion}

Scanning electron microscopy (SEM) was used to investigate the morphology of GC materials with thin mercury film. The obtained results suggest that deposits of $\mathrm{Tl}$ were formed on the electrode surface (Fig. 1).

The variations of metals concentrations in the collected materials were presented in Table 1. The obtained results indicate the presence of analyzed elements $(\mathrm{Cu}$, $\mathrm{Cd}, \mathrm{Fe}, \mathrm{Pb}, \mathrm{Zn}$, and $\mathrm{Tl}$ ) in each of the analyzed biological materials. Their amounts varied depending on the test algae material. The cause may be a difference in the size of the specific surface of each alga. The material characterized by the highest specific surface exhibited an increased ability to accumulate metals.

Several potential causes of the presence of trace elements in the studied algae and sand can be distinguished. The place from which they originate, the Black Sea, is largely closed. No direct connection to the 


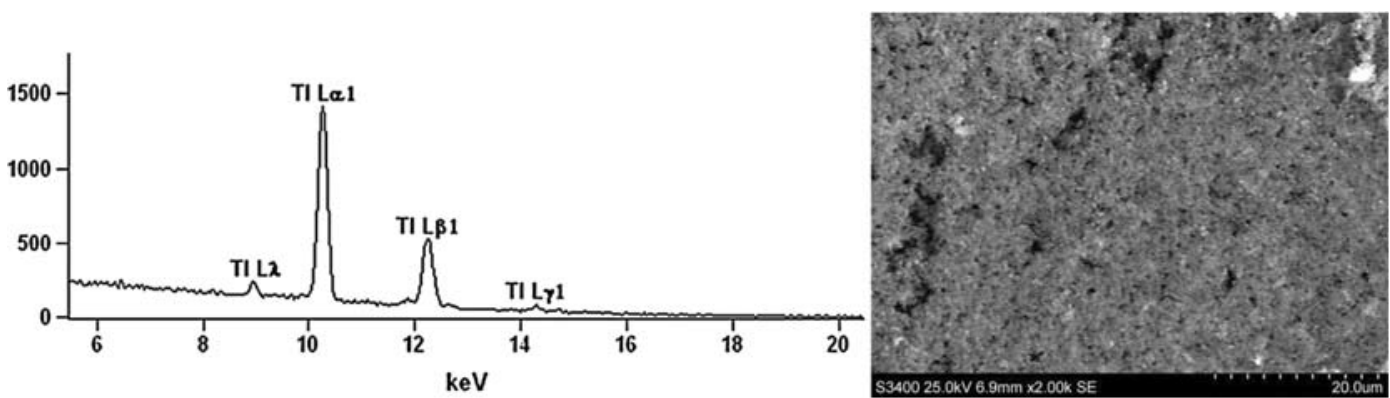

Fig. 1 Energy dispersive spectrum (left) and SEM image (right) of electrode surface showing thallium deposits

Atlantic Ocean and only a narrow connection to the Sea of Marmara via the Bosphorus does not provide proper water circulation. A steady supply of contaminants to the three great rivers, the Don and Kuban, which includes its outlet on the coast of Russia, and the Danube, which flows through Bulgaria, causes continuous pollution of the sea with wastewater containing metals. It is assumed that the Black Sea is one of the most polluted seas in the world.

Subsequently, there are several port cities located on the east coast of Bulgaria. The main ones are the sea ports of Burgas and Varna. Leaks from tankers, transporting the oil to a large extent, result in an increase of copper and iron content in the seawater. Potential leakage from water vessels is also a threat to the environment, increasing the level of water contamination with metals. The development of the tourism sector in the western zone of the Black Sea during recent years is another factor which can influence on the water contaminations. On the coast of Bulgaria, there is no sewage treatment plant, designed especially for the proper functioning during the tourist season. Hence, part of the sewage enters the sea causing pollution and death of marine organisms.

Table 2 summarizes the results of research regarding the nature of the test material, the place of its collection, and the average concentrations of metals (Jitar et al. 2015; Topcuoglu et al. 2001; Strezov and Nonova 2009; Awheda et al. 2015; Kumar et al. 2015; Birungi and Chirwa 2015).

The amount of metals accumulated by the algae was associated with their place of occurrence. Algae

Table 1 Cadmium, lead, thallium, copper, zinc, and iron content in algae from west coast of the Black Sea

\begin{tabular}{|c|c|c|c|c|c|c|}
\hline Metals & $\begin{array}{l}\text { Arithmetic mean } \\
{\left[\mu \mathrm{g} \mathrm{g}^{-1}\right]}\end{array}$ & $\begin{array}{l}\text { Minimum } \\
{\left[\mu \mathrm{g} \mathrm{g}^{-1}\right]}\end{array}$ & $\begin{array}{l}\text { Maximum } \\
{\left[\mu \mathrm{g} \mathrm{g}^{-1}\right]}\end{array}$ & $\begin{array}{l}\text { Median } \\
{\left[\mu \mathrm{g} \mathrm{g}^{-1}\right]}\end{array}$ & $\begin{array}{l}\text { Standard deviation } \\
\mathrm{SD}\left[\mu \mathrm{g} \mathrm{g}^{-1}\right]\end{array}$ & $\begin{array}{l}\text { Relative standard } \\
\text { deviation \% RSD }\end{array}$ \\
\hline \multicolumn{7}{|c|}{ Algae Cystoseira sp. } \\
\hline Cadmium & 1.992 & 1.9900 & 1.9950 & 1.9920 & 0.0025 & 0.13 \\
\hline Lead & 0.1993 & 0.1980 & 0.2010 & 0.1990 & 0.0015 & 0.77 \\
\hline Thallium & 1.5980 & 1.1160 & 2.2100 & 1.4680 & 0.5580 & 34.92 \\
\hline Copper & 1.9927 & 1.9900 & 1.9960 & 1.9920 & 0.0031 & 0.16 \\
\hline Zinc & 3.9843 & 3.9810 & 3.9880 & 3.9840 & 0.0035 & 0.09 \\
\hline Iron & 418.3277 & 418.3210 & 418.3350 & 418.3270 & 0.0070 & 0.02 \\
\hline \multicolumn{7}{|c|}{ Algae Ulva sp. } \\
\hline Cadmium & 4.0970 & 4.0950 & 4.0990 & 4.0980 & 0.0021 & 0.05 \\
\hline Lead & 0.2053 & 0.2040 & 0.2070 & 0.2050 & 0.0015 & 0.75 \\
\hline Thallium & 2.1180 & 1.6200 & 2.4900 & 2.1900 & 0.3400 & 16.05 \\
\hline Copper & 4.0977 & 4.0950 & 4.1000 & 4.0980 & 0.0025 & 0.06 \\
\hline Zinc & 0.2050 & 0.2040 & 0.2060 & 0.2050 & 0.0010 & 0.49 \\
\hline Iron & 799.1827 & 799.1800 & 799.1860 & 799.1800 & 0.0031 & 0.0004 \\
\hline
\end{tabular}




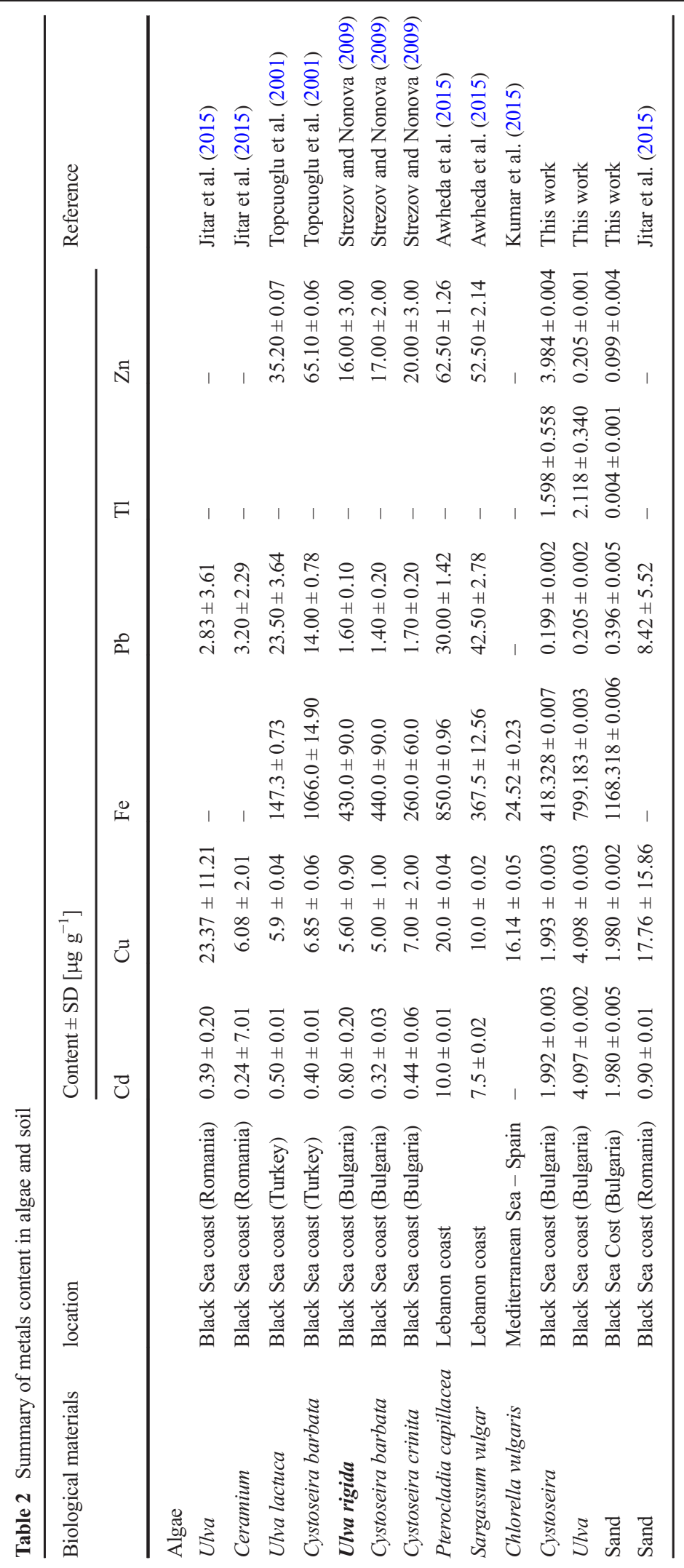


Table 3 Analysis of the standard reference material NMIJ CRM 7405-a in Seaweed (Hijiki) produced by National Metrology Institute of Japan (NMIJ) and Chinese soil GBW 07401 for metals

\begin{tabular}{llll}
\hline Elements & $\begin{array}{l}\text { The value given } \\
\text { by certified } \\
{\left[\mu \mathrm{g} \mathrm{g}^{-1}\right]}\end{array}$ & $\begin{array}{l}\text { The value indicated } \\
\text { in the analysis } \\
{\left[\mu \mathrm{g} \mathrm{g}^{-1}\right]}\end{array}$ & $\begin{array}{l}\text { Recovery } \\
{[\%]}\end{array}$ \\
\hline $\mathrm{Cu}$ & $1.55 \pm 0.07$ & $1.5321 \pm 0.0540$ & 98.84 \\
$\mathrm{Cd}$ & $0.79 \pm 0.02$ & $0.7690 \pm 0.0381$ & 97.34 \\
$\mathrm{Fe}$ & $311 \pm 11$ & $313.5401 \pm 5.2802$ & 100.82 \\
$\mathrm{~Pb}$ & $0.43 \pm 0.03$ & $0.4441 \pm 0.0321$ & 103.26 \\
$\mathrm{Zn}$ & $13.4 \pm 0.5$ & $12.9601 \pm 0.3540$ & 96.72 \\
$\mathrm{Tl}$ & $1.00 \pm 0.2$ & $0.8902 \pm 0.0901$ & 89.00 \\
\hline
\end{tabular}

of the species Cystoseira barbata, occurring on the Black Sea coast in Bulgaria, absorb smaller amounts compared to the same species from the area of northern Turkey. According to the literature data (Jitar et al. 2015; Topcuoglu et al. 2001; Strezov and Nonova 2009; Awheda et al. 2015; Kumar et al. 2015; Birungi and Chirwa 2015), algae Ulva lactuca contain high amounts of zinc, copper, and iron species in comparison with the Ulva rigida. Many authors confirm that iron is accumulated in the highest quantities by all algae. Research conducted in 1994-1997 was focused on the content of individual metals in algae from the Turkish coast of the Sea Black. The results showed that the concentration of cadmium, lead, and zinc present in the algae of the species Cystoseira in the period 19941996 has been reduced by almost two times; however, a year later, it increased again (Awheda et al. 2015). The results obtained in the present study for this type of algae show a lower content of zinc, copper, lead, and iron.

Approximately five times higher concentration of cadmium was observed in algae from the Bulgarian coast, than in algae of the species Cystoseira in the area of Turkey. This study showed more than 70 times lower content of lead compared to algae from the southern zone of the Black Sea. The analysis of algae of the species Cystoseira accumulated on the Turkish coast as well as in Bulgaria proved that among the analyzed metal elements, iron was characterized by the highest concentration in the biological material.

Analysis of metals content in algae Ulva, both from the Turkish coast and from Bulgaria, showed that the accumulation of iron was highest among all the studied metals. Its quantity is higher by five times in the biological material gathered on the west coast of the Black Sea, compared to algae in the area of Turkey. Results of this study indicate a similar after-level content of zinc and lead in the algae from the Bulgarian coast, which was at $0.2050 \mu \mathrm{g} \mathrm{g}^{-1}$ and $0.2053 \mu \mathrm{g} \mathrm{g}^{-1}$, respectively. The analysis demonstrated that the concentration of cadmium was eight times higher in algae of the Ulva gathered in Bulgaria.

Comparison of the results obtained for sand from the Bulgarian coastal zone with theaverage concentrations of metals in the coastal sand from Romania indicates higher contents of $\mathrm{Cu}$ and $\mathrm{Pb}$ in samples of sand from Romania analyzed in 2012. This may be due to a higher degree of contamination of rivers flowing into the country. The results presented in the framework of this study indicate that the cadmium content in the sand of the coast of Bulgaria was higher by two times, compared to the sand from the Romanian waterfront.

Despite the high toxicity of thallium and its harmful effect on the environment, there is little information regarding its content in algae. The research carried out so far was focused on the possibility to use green algae to remove thallium from the contaminated areas. For this purpose, algae belonging to Scenedesmus acuminutus, Chlorella vulgaris, and Chlamydomonas reinhardtii species, which were taken from the vicinity of the dam Hartbeespoort in South Africa, were studied. The process efficiency was highest when the amount of metal was less than $150 \mathrm{mg} \mathrm{L}^{-1}$. From all the analyzed algae species, Chlorella vulgaris showed the highest absorption of thallium (Kumar et al. 2015; Birungi and Chirwa 2015).

In order to control the analytical quality, the precision of the proposed method during analysis of $\mathrm{Tl}$ in the studied samples was compared with a certified reference material - GBW 07401 soil of Chinese origin, containing $1.0 \pm 0.2 \mu \mathrm{g} \mathrm{g}^{-1}$ of $\mathrm{Tl}$. 
In order to determine the accuracy and precision of the analytical method for analysis of $\mathrm{Cu}, \mathrm{Cd}, \mathrm{Fe}, \mathrm{Pb}$, and $\mathrm{Zn}$, the certificated material NMIJ CRM 7405-a: trace elements and arsenic compounds in seaweed (Hijiki) produced by the National Metrology Institute of Japan (NMIJ) were processed in each batch.

The results obtained with the certified standard were within the margin of error of the employed method, hence it may be established that the method is characterized by appropriate accuracy in order to determine the concentration of metals (Table 3 ). The collected samples were analyzed, and its was established that the results do not differ significantly, which indicates the repeatability of results obtained by this method.

\section{Conclusion}

The results indicate that the algae derived from the species Cystoseira and Ulva from coast of Black Sea accumulated metals in different amount. In the analyzed algae metals like: cadmium, iron, zinc, and copper, lead and thallium were present. From all of analyzed elements in the biological material, iron was present at the highest concentrations. Research has shown that thallium is largely accumulated in all of the analyzed algae. Due to the fact that the algae often are serve as a component of food, it can cause a risk to the consumer and introduce the $\mathrm{Tl}$ in example human or animal body.

The results indicate that the levels of zinc and lead accumulated in Ulva and Cystoseira pose a threat to the environment, because the amount accumulated is high, which can cause changes in the proper functioning of algae, and can also be included in the trophic chain through algae ingestion.

The possibility of accumulation of metals by algae Ulva and Cystoseira makes them natural indicators of environmental pollution.

Acknowledgments The authors are grateful to L. Lawniczak and M. Gaj for assistance during the preparation of the manuscript.

Funding Information This work was supported by the Polish Higher Educations as Project No 03/32/DSPB/0800 and No 03/31/ DSPB/0357.

Open Access This article is licensed under a Creative Commons Attribution 4.0 International License, which permits use, sharing, adaptation, distribution and reproduction in any medium or format, as long as you give appropriate credit to the original author(s) and the source, provide a link to the Creative Commons licence, and indicate if changes were made. The images or other third party material in this article are included in the article's Creative Commons licence, unless indicated otherwise in a credit line to the material. If material is not included in the article's Creative Commons licence and your intended use is not permitted by statutory regulation or exceeds the permitted use, you will need to obtain permission directly from the copyright holder. To view a copy of this licence, visit http://creativecommons.org/licenses/by/4.0/.

\section{References}

Akcali, I., \& Kucuksezgin, F. (2011). A biomonitoring study: Heavy metals in macroalgae from eastern Aegean coastal areas. Marine Pollution Bulletin, 62, 637-645. https://doi. org/10.1016/j.marpolbul.2010.12.021.

Awheda, I., Ahmed, A. Y., Smida, F. A., Elwahaishi, S. S., \& Fahej, M. A. S. (2015). Determination of heavy metals, Mn, $\mathrm{Fe}, \mathrm{Co}, \mathrm{Cu}, \mathrm{Zn}, \mathrm{Cd}$ and $\mathrm{Pb}$ in Sargassum vulgar and Pterocladia capillacea marine algae in Libyan coast of AlKhoms. International Journal of Advances Manufactures Technology, 3(3), 384-389.

Bazzi, A. O. (2014). Heavy metals in seawater, sediments and marine organisms in the Gulf of Chabahar, Oman Sea. Journal Ocean Marine Science, 5(3), 20-29. https://doi. org/10.5897/JOMS2014.0110.

Birungi, Z. S., \& Chirwa, E. M. N. (2015). The adsorption potential and recovery of thallium using green micro-algae from eutrophic water sources. Journal of Hazardous Materials, 299, 67-77. https://doi.org/10.1016/j.jhazmat.2015.06.011.

Campanella, L., Conti, M. E., Cubadda, F., \& Sucapane, C. (2004). Trace metals in seagrass, algae and molluscs from an uncontaminated area in the Mediterranean. Environmental Pollution, 111, 117-126. https://doi.org/10.1016/S02697491(99)00327-9.

Conti, M. E., \& Cecchetti, G. (2003). A biomonitoring study: Trace metals in algae and molluscs from Tyrrhenian coastal areas. Environmental Reveres, 93, 99-112. https://doi. org/10.1016/S0013-9351(03)00012-4.

Elfwing, T., \& Tedengreen, M. (2002). Effects of copper on the metabolism of three species of tropical oysters, Saccostrea cucullata, Crassostrea lugubris and Crassostrea belcheri. Aquaculture, 204, 157-166. https://doi.org/10.1016/S00448486(01)00638-X.

Ferrat, L., Gnassia-Barelli, M., Pergent-Martini, C., \& Romeo, M. (2003a). Mercury and non-protein thiol compounds in the seagrass Posidonia oceanica. Comparative Biochemistry and Physiology. C, 134, 147-155. https://doi.org/10.1016/S15320456(02)00220-X.

Ferrat, L., Pergent-Martini, C., \& Romeo, M. (2003b). Assessment of the use of biomarkers in aquatic plants for the evaluation of environmental quality: Application to seagrasses. Aquatic Toxicology, 65, 187-204. https://doi.org/10.1016/S0166445X(03)00133-4.

Goyer, R. A., \& Clarkson, T. W. (2001). In C. Klaassen (Ed.), Casarett and Doull's toxicology: The basic science of poisons (6th ed., pp. 811-827). New York: McGraw-Hill Health Professions Division. 
Hamed, A. H., \& Emara, A. M. (2006). Marine molluscs as biomonitors for heavy metal level in the Gulf of Suez. Red Sea Journal Marine System, 60, 220-234. https://doi. org/10.1016/j.jmarsys.2005.09.007.

Idris, A. M. (2008). Combining multivariate analysis and geochemical approaches for assessing heavy metal level in sediments from Sudanese harbors analog the Red Sea cost. Microchemical Journal, 90(2), 159-163.

Jitar, O., Teodosiu, C., Oros, A., Plavan, G., \& Nicoara, M. (2015). Bioaccumulation of heavy metals in marine organisms from the Romanian sector of the Black Sea. New Biotechnology, 32(3), 369-378. https://doi.org/10.1016/j.nbt.2014.11.004.

Karbowska, B. (2016). Presence of thallium in the environment: Sources of contaminations, distribution and monitoring methods. Environmental Monitoring and Assessment, 188, 640. https://doi.org/10.1007/s10661-016-5647-y.

Karbowska, B., \& Zembrzuski, Z. (2016). Fractionation and mobility of thallium in volcanic ashes after eruption of Eyjafjallajökull (2010) in Iceland. Bulletin of Environmental Contamination and Toxicology, 97(1), 3743. https://doi.org/10.1007/s00128-016-1831-6.

Khaled, A., \& Hussein, A. (2014). Determination of metals in tuna species and bivalves from Alexandria, Egypt. Egyptian Journal of Aquatic Research, 40, 9-17. https://doi. org/10.1016/j.ejar.2014.02.003.

Korfali, S. I., Hawi, T., \& Mroueh, M. (2013a). Evaluation of heavy metals content in dietary supplements in Lebanon. Chemistry Central Journal, 7(1), 10. https://doi. org/10.1186/1752-153X-7-1023.

Korfali, S. I., Mroueh, M., Al-Zein, M., \& Salem, R. (2013b). Metal concentration in commonly used medicinal herbs and infusion by Lebanese population: Health impact. Journal of Food Research, 2(2), 70-80. https://doi.org/10.5539/jfr.v2 $\mathrm{n} 2 \mathrm{p} 70$.

Kumar, S. K., Dahms, H. U., Won, E. J., Lee, J. S., \& Shin, K. H. (2015). Microalgae - A promising tool for heavy metal remediation. Ecotoxicology and Environmental Safety, 113, 329-352. https://doi.org/10.1016/j.ecoenv.2014.12.019.

Lukaszewski, Z., Karbowska, B., Zembrzuski, W., \& Siepak, M. (2012). Thallium in fractions of sediments formed during the 2004 tsunami in Thailand. Ecotoxicology and Environmental Safety, 80, 184-189. https://doi.org/10.1016/j. ecoenv.2012.02.026.

Maanan, M. (2008). Heavy metal concentrations in marine mollusks from the Moroccan coastal region. Environmental Pollution, 153, 176-183. https://doi.org/10.1016/j. envpol.2007.07.024.

Nicholson, S., \& Lam, K. S. (2005). Pollution monitoring in Southeast Asia using biomarkers in the mytilid mussel Perna viridis (Mytilidae: Bivalvia). Environmental International Journal, 31, 121-132. https://doi.org/10.1016 /j.envint.2004.05.007.

Nordberg, G. F., Nogawa, K., Nordberg, M., \& Friberg, L. T. (2011). In G. F. Nordberg, B. A. Fowler, M. Nordberg, \&
L. T. Friberg (Eds.), Handbook on the toxicology of metals (3rd ed., pp. 446-609). Burlington: Academic Press.

Rodríguez-Mercado, J. J., \& Altamirano-Lozano, M. A. (2013). Genetic toxicology of thallium: A review. Drug and Chemical Toxicology, 36(3), 369-383.

Stanly, Y. M., Lam, K. S., Martin, M., \& Calwell, W. (2008). The use of selected genotoxicity assays in green mussels Perna viridid a validation study in Hong Kong coastal water. Marine Pollution Bulletin, 83, 1521-1529. https://doi. org/10.1016/j.marpolbul.2008.03.006.

Strezov, A., \& Nonova, T. (2009). Influence of macroalgal diversity on accumulation of radionuclides and heavy metals in Bulgarian Black Sea ecosystems. Journal of Environmental Radioactivity, 100, 144-150. https://doi.org/10.1016/j. jenvrad.2008.09.007.

Topcuoglu, S., Güven, K. C., Kırbasoglu, C., Gungor, N., Unslu, S., \& Yilmaz, Y. Z. (2001). Bulletin of Environmental Contamination and Toxicology, 67, 288-294.

Topcuoglu, S., Güven, K. C., Balkis, N., \& Kibasoglu, . (2003). Heavy metal monitoring of marine algae from the Turkish coast of the Black Sea, 1998-2000. Chemosphere, 52, 16831688. https://doi.org/10.1016/S0045-6535(03)00301-1.

Vlahogianni, M., Dassenakis, M., Scoullos, M. J., \& Valavanidis, A. (2007). Integrated use of biomarkers (superoxide dismutase, catalase and lipid peroxidation) in mussels Mytilus galloprovincialis for assessing heavy metals pollution in coastal areas from the Saronikos' gulf of Greece. Marine Pollution Bulletin, 4, 1361-1371. https://doi.org/10.1016/j. marpolbul.2007.05.018

Yap, C. K., Ismail, A., Tan, S. G., \& Rahim, A. (2002). Can the shell of the green-lipped mussel Perna viridis from the west coast of peninsular Malaysia be a potential biomonitoring material for $\mathrm{cd}, \mathrm{Pb}, \mathrm{Zn}$. Estuarine, Coastal and Shelf Science, 57, 623-630. https://doi.org/10.1016/S0272-7714(02 00401-8.

Zelika, B., Lukic, S., \& Pezelj, D. (2003). Biomonitoring of heavy metal and arsenic on the east coast of the middle Adriatic Sea using Mytilus galloprivinsialos. Marine Pollution Bulletin, 56, 176-183. https://doi.org/10.1016/j.nimb.2005.11.050.

Zortia, I., Zarragoitia, M., Soto, M., \& Gajaraville, P. (2006a). Biomarkers in mussels from a copper site gradient (Visnes, Norway) an integrated biochemical, histochemical and histological study. Aquatic Toxicology, 78, 109-116. https://doi. org/10.1016/j.aquatox.2006.02.032.

Zortia, I., Ortiz-Zarragoitia, M., Soto, M., \& Cajaraville, M. P. (2006b). Biomarkers in mussels from a copper site gradient (Visnes, Norway): an integrated biochemical, histochemical and histological study. Aquatic Toxicology, 78, 109-116. https://doi.org/10.1016/j.aquatox.2006.02.032.

Publisher's Note Springer Nature remains neutral with regard to jurisdictional claims in published maps and institutional affiliations. 